Evidence is accumulating to substantiate the view that the oxytocic effects of $\mathrm{E}$ prostaglandins on uterine myometrium are much more pronounced than those of the $F_{a}$ prostaglandins. In the induction of labour at term the available evidence suggests that the effective dose range for $F_{2 a}$ is about 5 to 10 times that for $E_{2}$ (Karim et al., 1969; Embrey, 1970). So far personal experience of the $F$ prostaglandins in early pregnancy extends to only six cases. The dose range was 2 $5 \mu \mathrm{g} . / \mathrm{min}$. and the total amount infused varied from 820 to $3,150 \mu \mathrm{g}$. Only in one case (receiving the largest dose) was abortion successfully induced, clearly indicating the superiority of prostaglandin $\mathrm{E}_{2}$ in early pregnancy too. These observations are not at variance with those of Karim and Filshie (1970). They have just reported successful induction of abortion with $\mathrm{F}_{2 \mathrm{a}}$ in 14 out of 15 cases, but they used a very much higher dosage (infusion rate $50 \mu \mathrm{g} . / \mathrm{min}$.; infusion time about 4 to 27 hours) and there were frequent sideeffects (diarrhoea and vomiting). No noticeable side-effects could be ascribed to the infusion in any of the cases in this series. The patients were composed and symptom-free. Two vomited, but in each instance only when abortion was well advanced. No significant or constant changes in pulse or blood pressure were recorded in the cases.

It would be unwise, on such limited experience, to make extravagant claims for the use of $E$ prostaglandins in the termination of pregnancy. Nevertheless, the results so far are encouraging. The technique is simple and merely entails making an intravenous infusion, while it seems to be effective at any gestational age. Present methods of inducing abortion are not entirely satisfactory. Especially in the mid-trimester, the risks of one-stage evacuation (from trauma, haemorrhage, and infection) are great, while the alternatives-for example, irritant pastes, intra-amniotic hypertonic saline, or glucose injections - carry their own dangers. If the efficacy and safety of the prostaglandin $\mathrm{E}$ infusion is corroborated in extended trials it may well be a valuable therapeutic procedure in clinical practice.

I wish to thank Professor J. A. Stallworthy for advice and encouragement and gratefully acknowledge gifts of prostaglandins from Dr. J. Pike, of the Upjohn Co., and Dr. D. A. van Dorf, of the Unilever Research Laboratory.

\section{REFERENCES}

Bergström, S., Carlson, L. A., and Weeks, J. R. (1968). Pharmacological Reviews, 20, 1 .

Embrey, M. P. (1969). Fournal of Obstetrics and Gynaecology of the British Commonwealth, 76, 783.

Embrey, M. P. (1970). British Medical fournal, 2, 256.

Embrey, M. P., and Morrison, D. L (1968). 7ournal of Obstetrics and Gynaecology of the British Commonwealth, 75, 829 .

Karim, S. M. M. Trussell, R. R., Hillier, K., and Patel, R. C. (1969) Fournal of Obstetrics and Gynaecology of the British Commonwealth, 76, 769.

Karim, S. M. M., and Filshie, G. M. (1970). Lancet, 1, 157.

Pickles, V. R. (1969). Nature, 224, 221.

\title{
Study of Proteins and Fibrinolysis in Patients with Glomerulonephritis
}

\author{
E. N. WARDLE, ${ }^{*}$ M.A., M.B., M.R.C.P. ; I. S. MENON, $\dagger$ M.B., PH.D. ; S. P. RASTOGI, $\ddagger$ M.B., M.R.C.P.ED., D.T.M.\&H.
}

\begin{abstract}
Cummary: Plasma and urine fibrinolysis were studied in 36 patients with glomerulonephritis and proteinuria. In $40 \%$ of these plasma fibrinolytic activator activity was moderately reduced and fibrinolytic inhibitors were increased. Globulins with antiplasmin effect were raised, particularly in the earlier months. Both the serum cholesterol and the plasma fibrinogen were related to the level of serum albumin, and those patients with high fibrinogen levels were also those with poor plasma fibrinolytic activator and those showing a steady deterioration. Urinary fibrinolysis was greatly reduced in most patients and bore no relation to plasma fibrinolysis levels. Hence urokinase is not derived from circulating plasminogen activator.
\end{abstract}

\section{Introduction}

Patients with nephrotic syndrome are apt to develop venous or even pulmonary artery thrombosis (Levin et al., 1967), especially when given steroid therapy. This tendency has been attributed to raised levels of plasma fibrinogen and of inhibitors of fibrinolysis found in the increased $\alpha_{2}$-globulin and $\beta$-globulin fractions. Few detailed studies of systemic fibrinolysis have been made and even less attention has been paid to possible immunological inhibition of local fibrinolysis within the kidney. It is, however, known that fibrin is deposited in the kidney in experimental glomerulonephritis (Vassalli and McCluskey, 1964) and that patients with the nephrotic syndrome may show accelerated thromboplastin generation. Kincaid-Smith et al. (1968) reported promising results with heparin therapy; this is logical, as immuno-

\footnotetext{
* Senior Medical Registrar and M.R.C. Clinical Research Fellow. † Senior Research Registrar.

$¥$ Senior Research Associate, Renal Unit

The Royal Victoria Infirmary, Newcastle upon Tyne NE1 4LP.
}

fluorescent studies may show deposition of fibrin, especially in the proliferative forms of human glomerulonephritis.

We report here the results of a survey of fibrinolysis in a group of 36 patients with glomerulonephritis and proteinuria, designated as "nephrotic."

\section{Methods}

Fasting blood samples and early morning urine collections were taken from nephrotic patients. Most were attending for follow-up in the M.R.C. Nephrotic Syndrome Trial. Renal biopsies had shown that five had "minimal change" pephritis, 13 proliferative glomerulonephritis, 11 established end-stage chronic glomerulonephritis, and seven "membranous change," of which two were due to amyloid and five fell into the category of idiopathic membranous glomerulonephritis. Those with minimal change glomerulonephritis had been treated for a mean period of $\mathbf{2 . 3}$ years, those with proliferative glomerulonephritis for 2.0 years, and those with membranous glomerulonephritis for 2.4 years; those with established chronic glomerulonephritis had been on supportive regimens for an average of four years, but it is impossible to designate the duration of their illness.

\section{Techniques}

Serum proteins and albumin and serum cholesterol were measured in the artificial kidney laboratory by Autoanalyser methods together with the creatinine clearance.

Plasma fibrinogen was estimated by the method of Ratnoff and Menzie (1951).

Euglobulin lysis time was estimated by Von Kaulla's (1963) method slightly modified by. Menon et al (1968). It can be expressed in units by multiplying the reciprocal of the lysis time in minutes by 10,000. A logarithmic plot of lysis time against units of activity shows a linear relationship. The normal euglobulin lysis time is $\mathbf{4 0 - 1 1 0 ~ u n i t s . ~}$ 
Fibrinolytic inhibitors of urokinase were estimated according to the method of McNichol et al. (1963) expressed as units, with normal values of 40-120.

Urine fibrinolytic activity was assayed on 18 specimens on fibrin plates by comparison of serial dilutions of urine against standard urokinase dilutions. The activity is expressed as Plough units per $100 \mathrm{mg}$. of creatinine, and normal levels are over 200 units.

Serum levels of globulins $\alpha_{1}$-antitrypsin (M.W. 60,000), $\alpha_{2}$ macroglobulin (M.W. 900,000), and $\beta$-lipoprotein 2,000,000) were estimated by radial diffusion in agar plates containing specific antisera (Mancini et al., 1965). For convenience results are expressed as a percentage of normal values obtained from pooled sera.

Urine trypsin inhibitor was estimated by the method of Faarvang (1959) as the inhibitory effect of urine on the digestion of $3 \%$ casein by standard concentrations of trypsin. Normal trypsin inhibitor values in urine were up to about 6 units per ml., with a mean of 2.4 units.

Serum fibrin degradation products were estimated on serum specimens collected in aprotinin (Trasylol) and later clotted by thrombin, the Burroughs Wellcome fibrinogen assay kit being used. In normal sera fibrin degradation products are detectable at a level of $5 \mu \mathrm{g} . / \mathrm{ml}$.

\section{Results and Comments}

An overall impression of the range of values among these 36 nephrotic patients for the estimations of albumin, cholesterol, fibrinogen, and the various globulins, together with the fibrinolytic status in terms of plasma activator (euglobulin lysis time), plasma urokinase inhibitors, and urine fibrinolysis is given in Fig. 1. Normal values lie between the ruled lines,

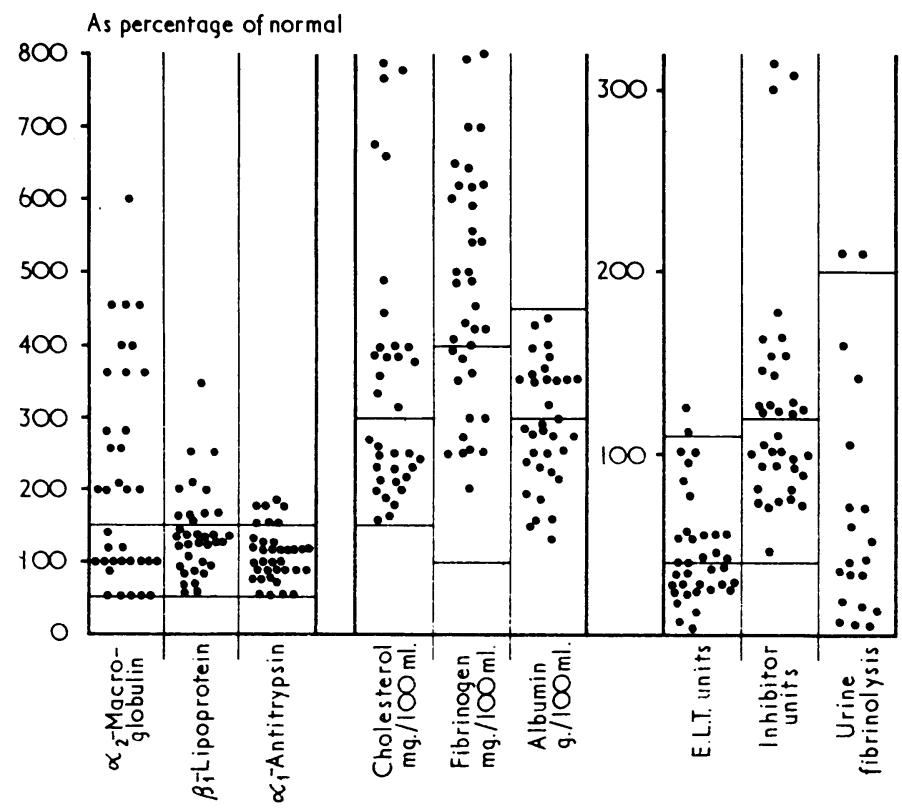

FIG. 1.-Protein and cholesterol estimations.

and it will be seen that, in general, the patients have lower levels of serum albumin and raised levels of serum cholesterol and fibrinogen, and that many have raised values for serum $\alpha_{2}$-macroglobulin and $\beta$-lipoprotein. Forty per cent. have a euglobulin lysis time longer than normal, indicating diminished plasma fibrinolysis, and $40 \%$ have raised levels of fibrinolytic inhibitors. There was, however, no direct correlation between lower euglobulin lysis time values and the rise in inhibitors, or the level of blood urea, or creatinine; nor could correlations be established between the level of fibrinolytic inhibitors as assayed and the levels of individual globulins selected for assay because of their known antiplasmin effect. This contrasts with our published values (Wardle and Menon, 1969) for normal patients, in whom a relationship was shown between $\beta$-lipoprotein and both the euglobulin lysis time and the inhibitor levels. Strikingly, urine fibrinolysis is much reduced in most of the patients, but did not correspond with the level of plasma activator activity; nor was the reduction of urine fibrinolysis directly proportional to a reduction of creatinine clearance.

The serum $\alpha_{1}$-antitrypsin values are not abnormal. This is an acute-phase reactive protein and in an inflammatory state such as glomerulonephritis raised values might be expected. The molecule, however, is small (M.W. 60,000) and in the presence of proteinuria, as in this group of patients, its loss in the urine is to be expected. For this reason, and to try to explain the poor urine fibrinolysis, urine trypsin inhibitor values were estimated. Normal inhibitor values were up to 6 units per $\mathrm{ml}$. (average 2.4 units) but the nephrotic urines showed appreciable trypsin inhibition, with values ranging from 3.6 to 26.0 and with a mean of 14.1 inhibitor units \pm 7.4 . This seems, however, insufficient to account entirely for poor urine fibrinolysis, and a failure of urokinase production by the kidney in nephrosis must be assumed.

To ascertain the role of renal fibrin deposition in the pathogenesis of renal disease (cf. Vassalli and McCluskey, 1965) serum fibrin degradation products were estimated randomly in 30 of these patients with glomerulonephritis. If a value of $40 \mu \mathrm{g} . / \mathrm{ml}$. is taken as abnormal 5 out of 30 patients had positive fibrin products. Probably serial assays on patients will show that this occurs intermittently in the course of the disease of many patients. The results are summarised in Table $\mathbf{I}$.

TABLE I.-Incidence of Serum Fibrin Products

\begin{tabular}{l|c|c|c|c}
\hline & $\begin{array}{c}\text { Glomerulo- } \\
\text { nephritis }\end{array}$ & $\begin{array}{c}\text { Chronic } \\
\text { Stage }\end{array}$ & $\begin{array}{c}\text { Acute } \\
\text { Nephritis }\end{array}$ & $\begin{array}{c}\text { Malignant } \\
\text { Hypertension }\end{array}$ \\
\hline $\begin{array}{l}\text { Positive at } 40 \mu \mathrm{G} / \mathrm{ml} . \ldots \\
\text { Positive at } 20 \mu \mathrm{G} / \mathrm{ml} . \ldots\end{array}$ & $\begin{array}{c}5 / 30(17 \%) \\
7 / 30(23 \%)\end{array}$ & $\begin{array}{c}4 / 32(12 \%) \\
10 / 32(31 \%)\end{array}$ & $\begin{array}{c}1 / 7(14 \%) \\
2 / 7(28 \%)\end{array}$ & $\begin{array}{c}5 / 22(23 \%) \\
15 / 22(68 \%)\end{array}$
\end{tabular}

Reference to Fig. 1 shows that two-thirds of the patients have plasma fibrinogen values over $400 \mathrm{mg} . / 100 \mathrm{ml}$. , and Fig. 2 shows a broadly inverse correlation between the serum

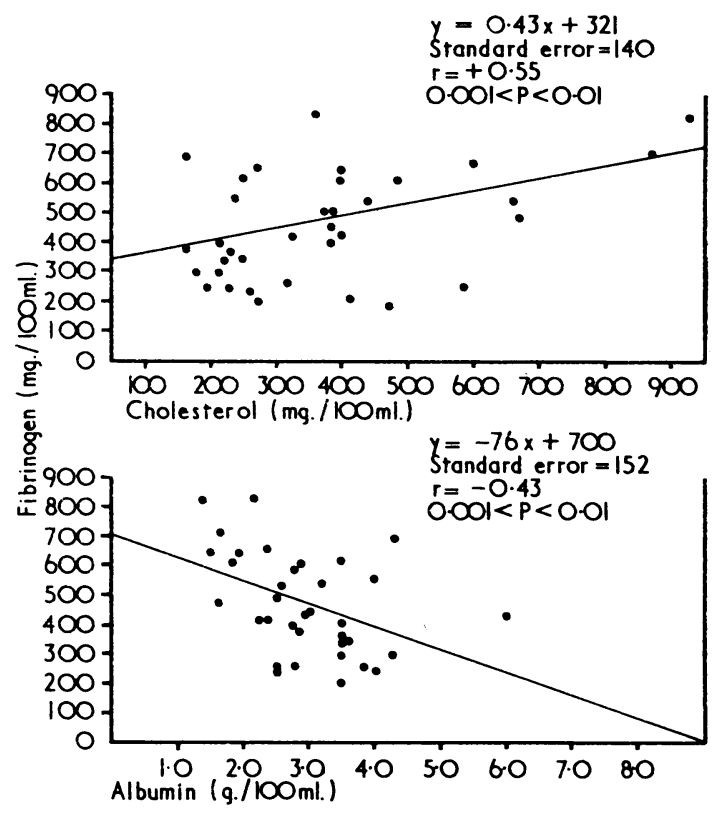

Fig. 2.-Relationship of plasma fibrinogen to serum cholesterol and serum albumin. 
albumin and the fibrinogen and also a relation between the plasma fibrinogen and the serum cholesterol.

An analysis of the cases grouped according to renal histology (Table II) shows that generally patients with "minimal change" have less disturbance of their fibrinolytic mechanism and retain a normal diastolic blood pressure and near-normal creatinine clearance. The "proliferative" and "membranous" groups have heavy proteinuria and reduced creatinine clearance, and many have raised levels of the three fibrinolytic inhibitor globulins. The mean diastolic blood pressure is raised in those with proliferative glomerulonephritis and in those with established chronic glomerulonephritis. These latter patients have the expected poor crea-

TABLE II.-Analysis According to Renal Histology

\begin{tabular}{|c|c|c|c|c|c|}
\hline No. & $\underset{\text { Lesion }}{\text { Minimal }}$ & Proliferative & Membranous & Chronic & \\
\hline & $\begin{array}{c}5 \\
2 \cdot 3 \text { years }\end{array}$ & $\begin{array}{c}13 \\
2 \cdot 0 \text { years }\end{array}$ & $\begin{array}{c}7 \\
2 \cdot 4 \text { years }\end{array}$ & $\begin{array}{c}11 \\
4.5 \text { years }\end{array}$ & \\
\hline $\begin{array}{l}\text { Cr. clearance } \\
\text { Diastolic B.P. } \\
\text { Proteinuria (g.24 } \\
\text { hours) } \\
\text { Albumin } \\
\text { Cholesterol } \\
\text { Fibrinogen } \\
\text { E.L.T. units } \\
\text { Inhibitors } \\
\alpha_{1} \text { Antitrypsin } \\
\beta \text {-Lipoprotein } \\
\alpha_{2} \text {-Macroglobulin }\end{array}$ & $\begin{array}{c}89 \pm 11 \\
74 \pm 24 \\
2 \cdot 2 \pm 0 \cdot 7 \\
2 \cdot 29 \pm 0 \cdot 66 \\
336 \pm 77 \\
444 \pm 169 \\
60 \pm 30 \\
119 \pm 33 \\
150 \pm 54 \\
133 \pm 16 \\
218 \pm 161\end{array}$ & $\begin{array}{c}42 \pm 26 \\
104 \pm 22 \\
\\
5 \cdot 2 \pm 4 \cdot 2 \\
2 \cdot 95 \pm 0 \cdot 75 \\
380 \pm 218 \\
477 \pm 190 \\
44 \pm 27 \\
161 \pm 135 \\
168 \pm 52 \\
158 \pm 82 \\
244 \pm 162\end{array}$ & $\begin{array}{c}57 \pm 25 \\
86 \pm 7 \\
5 \cdot 6 \pm 1 \cdot 54 \\
2 \cdot 64 \pm 0 \cdot 82 \\
375 \pm 157 \\
438 \pm 112 \\
43 \pm 18 \\
134 \pm 95 \\
196 \pm 61 \\
166 \pm 47 \\
281 \pm 114\end{array}$ & $\begin{array}{c}29 \pm 24 \\
104 \pm 20 \\
3 \cdot 8 \pm 2 \cdot 46 \\
3 \cdot 23 \pm 0 \cdot 78 \\
254 \pm 48 \\
510 \pm 185 \\
44 \pm 33 \\
103 \pm 32 \\
144 \pm 46 \\
106 \pm 32 \\
143 \pm 102\end{array}$ & $1 \%$ \\
\hline $\begin{array}{l}\text { E.L.T. }<40 \text { units } \\
\text { Inhibitors }>120 \\
\text { units } \\
\text { Fibrinogen }>500 \\
\text { mg./100 ml. } \\
\text { Cholesterol >300 } \\
\text { mg./100 ml. } \\
\alpha-M \text { acroglobulin } \\
>200 \% \\
\beta \text {-Lipoprotein } \\
>200 \% \\
\alpha \text {-Antitrypsin } \\
>200 \%\end{array}$ & $\begin{array}{c}\text { ercentage } P c \\
40 \\
40 \\
40 \\
60 \\
40 \\
20 \\
40\end{array}$ & $\begin{array}{c}\text { ts in Each } \\
38 \\
69 \\
54 \\
46 \\
62 \\
46 \\
69\end{array}$ & $\begin{array}{c}\text { up with Sig } \\
43 \\
28 \\
28 \\
71 \\
86 \\
43 \\
71\end{array}$ & $\begin{array}{c}\text { antly High } \\
73 \\
36 \\
45 \\
27 \\
27 \\
9 \\
45\end{array}$ & alue. \\
\hline
\end{tabular}

*Significance level using Snedecor F test.

E.L.T.= Euglobulin lysis time.

TABLE III.-Analysis According to Duration of Illness

\begin{tabular}{l|c|c|c|c}
\hline & $\begin{array}{c}\text { Less Than } \\
\text { One Year }\end{array}$ & $>$ One Year & $>3$ Years & $\begin{array}{c}\text { Chronic } \\
\text { Undeter- } \\
\text { mined }\end{array}$ \\
\hline Cr. Clearance* & $59 \pm 32$ & $57 \pm 30$ & $47 \pm 36$ & $26 \pm 23$ \\
Diastolic B.P.t & $92 \pm 14$ & $92 \pm 20$ & $106 \pm 18$ & $105 \pm 20$ \\
E.L.T. & $38 \pm 16$ & $44 \pm 26$ & $60 \pm 34$ & $36 \pm 33$ \\
Inhibitors & $124 \pm 67$ & $172 \pm 161$ & $155 \pm 82$ & $103 \pm 35$ \\
Albumin & $2 \cdot 64 \pm 0 \cdot 51$ & $2 \cdot 38 \pm 0 \cdot 18$ & $3 \cdot 14 \pm 0 \cdot 28$ & $3 \cdot 23 \pm 0 \cdot 24$ \\
Proteinuria (g./24 hours) & $5 \cdot 0 \pm 4 \cdot 7$ & $4 \cdot 4 \pm 2 \cdot 6$ & $4 \cdot 6 \pm 1 \cdot 9$ & $3 \cdot 8 \pm 2 \cdot 4$ \\
Cholesterol & $353 \pm 204$ & $467 \pm 174$ & $292 \pm 118$ & $254 \pm 48$ \\
Fibrinogen & $426 \pm 167$ & $480 \pm 134$ & $452 \pm 144$ & $510 \pm 184$ \\
$\% \alpha_{2}$-Macroglobulin & $322 \pm 151$ & $206 \pm 160$ & $211 \pm 105$ & $142 \pm 103$ \\
$\%$ \%-Lipoprotein & $169 \pm 80$ & $155 \pm 46$ & $139 \pm 38$ & $106 \pm 32$ \\
$\% \alpha_{1}$-Antitrypsin & $196 \pm 53$ & $155 \pm 60$ & $163 \pm 66$ & $144 \pm 47$ \\
\hline No. of Cases & 9 & 8 & 8 & 11 \\
\hline
\end{tabular}

* Significant at $1 \%$ level for Variance ratio.

+Significant at $5 \%$ level using Snedecor $F$ test.

Other values not significant. tinine clearance and $73 \%$ have poor fibrinolytic activator levels.

When the duration of the illness is considered (Table III) the creatinine clearance is seen to fall with time, while the diastolic blood pressure rises. Proteinuria lessens and accordingly the serum albumin restabilizes. The mean levels of globulins $\alpha_{2}$-macroglobulin, $\alpha_{1}$-antitrypsin, and $\beta$-lipoprotein are higher in the earlier phase of the illness, and the euglobulin lysis time is as likely to be prolonged at this stage as in the chronic endstage glomerulonephritis.

Of the 36 patients the illness had lasted for less than three years in 17. They were subdivided according to four separate criteria of deterioration: a creatinine clearance of below or above $50 \mathrm{ml} . / \mathrm{min}$., proteinuria over $4 \mathrm{~g} . /$ day, a euglobulin lysis time under the normal value of $\mathbf{4 0}$ units, or a fibrinogen value over $500 \mathrm{mg} . / 100 \mathrm{ml}$. For the two subdivisions of each category the relation to the other measurements (Table IV) show that a high fibrinogen level especially is associated with features of bad prognosis. Persistent heavy proteinuria is accompanied by more striking changes in the plasma proteins, cholesterol, and fibrinolytic system. Paradoxically, a low creatinine clearance is accompanied by a better state of the plasma proteins, but probably this is simply because as the glomerular filtration rate lessens proteinuria diminishes.

\section{Discussion}

Many patients with glomerulonephritis (and "immunosuppressive" therapy) proceed to long-term dialysis, steroids may have side-effects of their own and benefit mainly those with minimal change histology. The glomerulus may be damaged either by antibodies reacting with the glomerular basement membrane or because of the filtration of antigenantibody complexes (Dixon, 1968). In immune complex diseases glomerular permeability is increased by the direct action of the complexes themselves, indirectly by local platelet disintegration, releasing vasoactive amines; by the associated fixation of complement; and, finally, from the release of lysozymal hydrolysases from accumulating polymorph leucocytes. Fibrin and complexes are removed by phagocytic cells of the mesangium and by the proliferative endothelial response; but once complexes penetrate the basement membrane they localize and destroy the foot processes of the epithelial cells, so worsening proteinuria, and they are no longer accessible to phagocytosis. Fibrin probably plays an accessory part in glomerulonephritis, stimulating the proliferative response (Vassalli et al., 1965) and glomerular scarring as well as crescent formation if fibrin enters Bowman's capsule (Vassalli and McCluskey, 1964; Halpern et al., 1965). Hence local fibrinolysis is therefore important, a suggestion confirmed for acute glomerulonephritis (Goldschmidt and Marosvári, 1968; Humair, 1969; Kwaan et al., 1966; Maggiore et al., 1969).

In the earlier stages of progressive glomerulonephritis some $40 \%$ of patients have poor plasminogen activator production and $40 \%$ have inhibitors of fibrinolysis. Inhibitors and the plasma fibrinogen appear to be higher in proliferative glo-

TABLE IV.-Analysis of Criteria of Deterioration

\begin{tabular}{|c|c|c|c|c|c|c|c|c|c|c|c|c|c|}
\hline & & \multicolumn{3}{|c|}{ Fibrinogen $>500 \mathrm{mg} . / 100 \mathrm{ml}$} & \multicolumn{3}{|c|}{ E.L.T. $<40$ units } & \multicolumn{3}{|c|}{ G.F.R. $<50 \mathrm{ml} . / \mathrm{min}}$. & \multicolumn{3}{|c|}{ Proteinuria $>4$ g. $/$ day } \\
\hline & & + & - & $S^{*}$ & + & - & S* & + & - & $S^{*}$ & + & - & $S^{*}$ \\
\hline 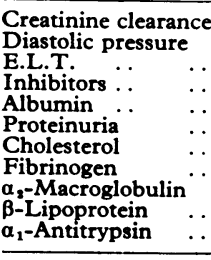 & \begin{tabular}{l|}
$\cdots$ \\
$\cdots$ \\
$\cdots$ \\
$\cdots$ \\
$\cdots$ \\
$\cdots$ \\
$\cdots$ \\
$\cdots$ \\
$\cdots$
\end{tabular} & $\begin{array}{c}43.9 \\
100 \\
37.1 \\
221 \\
2 \cdot 35 \\
6.5 \\
545 \\
211 \\
135 \\
188 \\
\end{array}$ & $\begin{array}{c}69 \cdot 6 \\
86 \\
47 \cdot 7 \\
84 \\
2 \cdot 66 \\
3 \cdot 5 \\
310 \\
305 \\
181 \\
169 \\
\end{array}$ & $\begin{array}{l}1.0 \% \\
1.0 \% \\
5.0 \% \\
0.1 \% \\
5.0 \% \\
1.0 \% \\
0.1 \% \\
5.0 \% \\
1.0 \%\end{array}$ & \begin{tabular}{|c|}
62 \\
75 \\
102 \\
$2 \cdot 48$ \\
$4 \cdot 8$ \\
433 \\
523 \\
306 \\
190 \\
168 \\
\end{tabular} & $\begin{array}{c}57 \\
93 \\
118 \\
2.57 \\
4 \cdot 7 \\
393 \\
412 \\
246 \\
147 \\
181 \\
\end{array}$ & $1.0 \%$ & $\begin{array}{c}101 \\
49 \cdot 3 \\
175 \\
2 \cdot 66 \\
2.4 \\
325 \\
470 \\
142 \\
125 \\
166 \\
\end{array}$ & $\begin{array}{c}86 \\
28 \cdot 5 \\
94 \\
2 \cdot 46 \\
3.8 \\
451 \\
441 \\
355 \\
183 \\
183 \\
\end{array}$ & $\begin{array}{c}5.0 \% \\
0.1 \% \\
5.0 \% \\
0.1 \%\end{array}$ & $\begin{array}{l}63 \\
90 \\
35 \cdot 1 \\
127 \\
2 \cdot 34 \\
502 \\
526 \\
298 \\
179 \\
176 \\
\end{array}$ & $\begin{array}{l}54 \\
93 \\
47 \cdot 8 \\
107 \\
2 \cdot 75 \\
\\
300 \\
380 \\
206 \\
143 \\
177 \\
\end{array}$ & $\begin{array}{l}5.0 \% \\
1.0 \% \\
0.1 \% \\
0.1 \% \\
5.0 \% \\
5.0 \%\end{array}$ \\
\hline $\begin{array}{l}\text { No. of cases } \\
\text { Score } \quad \text {. }\end{array}$ & $\cdots$ & 7 & 10 & 9 & 6 & 11 & 2 & 6 & 11 & 4 & 9 & 8 & 6 \\
\hline
\end{tabular}

*Significance level by student's $t$ test. Mean values for each group are recorded. 
merulonephritis. The contrast with the increase of fibrinolysis seen in the transient state of acute nephritis is notable. Furthermore, by the chronic stage some $70 \%$ of patients have poor activator production, but there is no clear relationship to the blood urea or creatinine. How much this can be attributed to a poor contribution to circulating activator by the kidney itself is debatable, but possibly the normal kidney contributes substantially to circulating plasminogen activator (Menon et al., 1968; Nowak et al., 1969). In many types of chronic renal disease urokinase output is diminished (McNichol et al., 1965; Nowak and Zahorska, 1966; Vreeken et al., 1966). It has long been felt that levels of urokinase and circulating plasminogen activator from undamaged endothelial cells do not correspond with one another, and our results confirm this. Though we have not shown how far poor urine fibrinolysis is due to poor urokinase production and how far to inhibitors filtered by the glomerulus, we have found a leak of proteolytic inhibitors, measured by their antitrypsin effect. Moreover, poor urine fibrinolysis, which occurred in all types of glomerulonephritis and was not confined to the chronic stage, could explain a tendency to persistence of casts in the tubules.

We do not wish to imply that the presence of fibrin degradation products are a specific indicator of intravascular coagulation, still less of fibrin deposition in the kidney alone. Nevertheless, raised titres usually indicate local lysis of microthrombi in small blood vessels. The $23 \%$ of random cases of glomerulonephritis showing positive fibrin degradation products corresponds to the $20 \%$ given by Wardle and Taylor (1968) and to the $22 \%$ found by Stiehm and Trygstad (1969) using a precipitin technique. For comparison, in malignant hypertension the figure is $68 \%$ and in this condition microangiopathy can often be found (Linton et al., 1969).

The analysis according to duration of disease (Table III) shows that in the earlier years of persistent immunological and inflammatory reaction there are greater changes in the reactive globulins. Fibrinogen levels, however, rise with duration and deterioration. Increased fibrinogen synthesis in nephrosis but a normal catabolic rate has been shown bv Takeda and Chen (1967) and a similar situation may occur in uraemia itself. The rise of globulins with a fibrinolytic inhibitor potential- $\alpha_{2}$-macroglobulin and $\beta$-lipoprotein-may be a direct consequence of albumin loss and plasma volume depletion. Catabolism of $\alpha_{2}$-macroglobulin is known to be reduced in nephrotics by an amount inversely proportional to the reduction of plasma volume (Kluthe et al., 1967).

Nephrotic patients with hyperlipaemia are, of course, liable to premature atherosclerosis. The serum cholesterol level is correlated with the plasma fibrinogen concentration (Suschke and Foldenauer, 1968) and both values can be related to the level of the serum albumin and hence to the degree of proteinuria. Those patients with high cholesterol and fibrinogen values are those with poor plasma fibrinolysis. $\beta$-lipoprotein is known to be a fibrinolytic inhibitor (Wardle and Menon, 1969), while raised triglyceride or cholesterol levels are accompanied by fibrinolytic inhibition (Spöttl et al., 1968; Sweet et al., 1966) and fatty acids may exert some regulatory action on fibrinogen synthesis (Pilgeram and Pickart, 1968). As regards glomerulonephritis a persistently high fibrinogen reflects a gloomy prognosis in terms of morbidity (Table IV). Naturally, deterioration of glomerular filtration rate for which measurement of creatinine clearance is short of ideal (Kim et al., 1969), is the feature that determines death from renal failure or a life on dialysis. Nevertheless the degree of proteinuria or the level of plasma fibrinogen is more closely related to the protein values that we have studied.

This study was originally made with a similar one on fibrinolysis in pregnancy and pre-eclamptic toxaemia (Wardle and Menon, 1969). In pregnancy there is a pronounced physiological reduction of plasminogen activator release. Thus patients who become pregnant might be expected to show either deterioration of their glomerulonephritis or venous thrombosis, and indeed in occasional patients this is so (Seftel and Schewitz, 1957; Fishberg, 1954). Even so, many nephrotic patients have an uneventful pregnancy (Studd and Blainey, 1969), probably owing to enhanced function of the reticuloendothelial system. This is a known effect of oestrogens (Nicol et al., 1952), but the potential of the reticuloendothelial system for clearing fibrin remains to be investigated (Lee and McCluskey, 1962).

Our thanks are due to Professor D. N. S. Kerr, under whose care these patients are, to Dr. R. Ashcroft for the kidney laboratory estimations, and to Dr. H. A. Dewar for the co-operation of the fibrinolysis unit. We are also obliged to Mr. Alan Martin and Mr. D. A. Piercy for technical assistance. One of us (E.N.W.) is indebted to the Scientific and Research Committee of the Royal Victoria Infirmary, Newcastle upon Tyne, for funds and latterly to the Medical Research Council.

\section{REFERENCES}

Dixon, F. J. (1968). American fournal of Medicine, 44, 493.

Faarvang, H. J. (1959). Acta Endocrinologica (Kobenhavn), 30, 285. Fishberg, A. M. (1954). Hypertension and Nephritis, 5th ed. Philadelphia, Lea and Febiger.

Goldschmidt, B., and Marosvàri, I. (1968). Klinische Wochenschrift, 46, 421.

Halpern, B., Milliez, P., Lagrue, G., Fray, A., and Morard, J. C. (1965). Nature, 205, 257.

Humair, L., Potter, E. V., and Kwaan, H. C. (1969). fournal of Laboratory and Clinical Medicine, $\mathbf{7 4}, 60$.

Kim, K. E,. Onesti, G., Ramirez, O., Brest, A. N., and Swartz, C. (1969). British Medical fournal, 4, 11.

Kincaid-Smith, P., Saker, B. M., and Fairley, K. F. (1968). Lancet, 2, 1360 .

Kluthe, R., Hagemann, U., and Kleine, N. (1967). Vox Sanguinis, 12 308

Kwaan, H. C., Humair, L. M., and Potter, E. V. (1966). Third International Congress of Nephrology. Abstracts: free communications, p. 226.

Lee, L., and McCluskey, R. T. (1962). Journal of Experimental Medicine, 116, 611 .

Levin, S. E., Zamit, R., and Schmaman, A. (1967). British Medical fournal, 1,153

Linton, A. L. et al. (1969). Lancet, 1, 1277.

McNichol, G. P., Barakat, A. A., and Douglas, A. S. (1965). Scottish Medical fournal, 10, 189.

McNichol, G. P., Gale, S. B., and Douglas, A. S. (1963). British Medical fournal, 1, 909.

Maggiore, Q., Jovanovic, B., and Baldini, G. (1969). Nephron, 6, 81.
Mancini, G., Carbonara, A. O., and Heremans, J. F. (1965). Immunochemistry, 2, 235.

Menon, I. S., Dewar, H. A., and Newell, D. J. (1968). Lancet, 1, 785

Nicol, T., Helmy, I. D., and Abou-Zikry, A. (1952). British fournal of Surgery, 40, 166.

Nowak. A., Kokot, F., Czekata, Z., Dosiak, I., and Kushka, J. (1969). Thrombosis et Diathesis Haemorrhagica, 21, 12.

Nowak, A., and Zahorska-Markiewicz, B. (1966). Polish Medical Fournal, $5,292$.

Pilgeram, L. O., and Pickart, L. R. (1968). fournal of Atherosclerosis Research, $8,155$.

Ratnoff, O. D., and Menzie, C. (1951). Journal of Laboratory and Clinical Medicine, 37, 316.

Seftel. H. C., and Schewitz, L. J. (1957). Fournal of Obstetrics and Gynaecology of the British Empire, 64, 862.

Slöttl, F., Holzknecht, F. and Braunsteiner, H. (1968). Fournal of Atherosclerosis Research, 8, 821 .

Stiehm, E. R., and Trygstad, C. W. (1969). American fournal of Med-

icine, 46, 774.
Studd. I. W. W., and Blainey, J. D. (1969). British Medical fournal, 1, 276.

Suschke, J., and Foldenauer, A. (1968). Deutsches medizinisches Wochenschrift, 931705.

Sweet. B., Rifkind, B. M.; and McNichol, G. P. (1966). Fournal of Atherosclerosis Research, 6, 359.

Takeda, Y., and Chen, A. Y. (1967). Journal of Laboratory and Clinical Medicine, 70, 678 .

Vassalli, P., and McCluskev, R. T. (1964). Annals of the New York Academy of Sciences, 116, 1052 .

Vassalli, P.. and McCluskey, R. T. (1965). American fournal of Medicine, 39. 179 .

Vassalli, P.. McCluskev, R. T., Gallo, G., and Baldwin, D. S. (1965). Clinical Research, 13, 316.

Von Kaulla. K. N. (1963). In Chemistry of Fibrinolysis, p. 79. Springfield, Illinois, Thomas.

Vreeken, I., Boomoaard. J., and Deggeller, K. (1966). Acta Medica Scandinavica, 180. 153 .

Wardle, E. N., and Menon, I. S. (1969). British Medical fournal, 2 625 .

Wardle. E. N., and Taylor, G. (1968). Fournal of Clinical Pathology, 21, 140. 